\title{
Coprolites in mid-Cambrian (Series 2-3) Burgess Shale-type deposits of Nevada and Utah and their ecological implications
}

\author{
JULIEN KIMMIG \& LUKE C. STROTZ
}

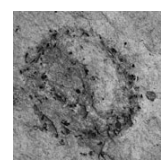

\begin{abstract}
Five types of coprolites, represented by 40 specimens from the Cambrian (Series 2-3) Burgess Shale-type deposits in the Pioche Shale of Nevada and the Spence Shale of Utah, are described. They are preserved in finely laminated deep-water calcareous mudstones. Round to ellipsoid features $13-42 \mathrm{~mm}$ in diameter consisting of black carbon film and variable amounts of skeletal fragments are interpreted as coprolites that were originally deposited in a burrow. Two kinds of elongated coprolites are also preserved and either consist of small pellets or skeletal debris. The pellets are typically 0.5 to $2 \mathrm{~mm}$ across and have a round to ellipsoid outline. Two different types of pellet-filled burrows are also present. The presence of organic tissue and skeletal fragments in some coprolites provides direct evidence of predatory or scavenging activity, and may advance understanding of the food chain in these Cambrian deposits. - Key words: coprolites, Spence Shale, Pioche Formation, Cambrian, ichnology, burrows, Burgess Shale-type deposit.
\end{abstract}

KimMig, J. \& STROTZ, L.C. 2017. Coprolites in mid-Cambrian (Series 2-3) Burgess Shale-type deposits of Nevada and Utah and their ecological implications. Bulletin of Geosciences 92(3), 297-309 (7 figures, 1 table). Czech Geological Survey, Prague, ISSN 1214-1119. Manuscript received March 8, 2017; accepted in revised form June 13, 2017; published online August 3, 2017; issued September 30, 2017.

Julien Kimmig \& Luke C. Strotz, Biodiversity Institute, University of Kansas, Lawrence, KS 66045, USA; jkimmig@ku.edu,lukestrotz@ku.edu

The Burgess Shale-type (BST) deposits of the Great Basin, extending across Western Utah and Nevada, offer significant insight into the ecology of the early to mid-Cambrian (Rigby 1983, Conway Morris \& Robison 1986, Lieberman 2003, Briggs et al. 2008). Whilst the faunas from the Great Basin BSTs have received focused attention, there have been few studies to date describing the relatively rare bromalites found in those deposits (Robison 1969; Conway Morris \& Robison 1986, 1988; English \& Babcock 2010). Bromalite is a term that covers all fossils that originated from the digestive tracts of animals, including coprolites (feces), regurgetites (material regurgitated from the oral cavity), in situ intestinal contents (cololites) and stomach contents (gastrolites) (Hunt 1992, Aldridge et al. 2006). The size and shape of particular bromalites can help to identify the source animal, and the preserved organic matter and fragments in the bromalites indicate what organisms were preyed upon. Early to mid-Cambrian bromalites are rare, as feces often disintegrate or get consumed before they can be preserved (Hollocher \& Hollocher 2012, Izumi \& Yoshizawa 2016). When preserved though, coprolites are particularly important, as they provide insight into the feeding ecology and biotic interactions of some of the first animal communities (Bengt- son 2002, Budd 2013), information that body fossils alone cannot provide.

Round, compressed coprolites are the most commonly observed coprolites in the Cambrian BST deposits of North America. They have been reported from the Stephen Formation (Sprinkle 1973, pl. 21, fig. 7), the Wheeler and Marjum Formations (Conway Morris \& Robison 1986, fig. 10.2), the Spence Shale (Conway Morris \& Robison 1988, fig. 32; and this paper), the Indian Springs Lagerstätte (English \& Babcock 2010, fig. 5f), and the Ravens Throat River Lagerstätte (Kimmig \& Pratt 2016, unpublished observation). Outside of North America, Cambrian BSTs yield a variety of coprolites, ranging from microscopic size to large pellet-filled burrows. Examples of microscopic phosphatized coprolites are known from the early Cambrian Sirius Passet Lagerstätte in Greenland (Peel 2015), the earliest Cambrian of the Yangtze Gorge in China (Chen \& Chen 1980), and the mid-Cambrian Gaotai Formation in southern China (Shen et al. 2014). Macroscopic coprolites have been better studied, but the record is still sparse. Specimens have been reported from the early Cambrian Paseky Shale of the Czech Republic (Mikulás 1995), the early Cambrian Maotianshan Shale of China (Vannier \& Chen 2005), the mid-Cambrian Kaili 


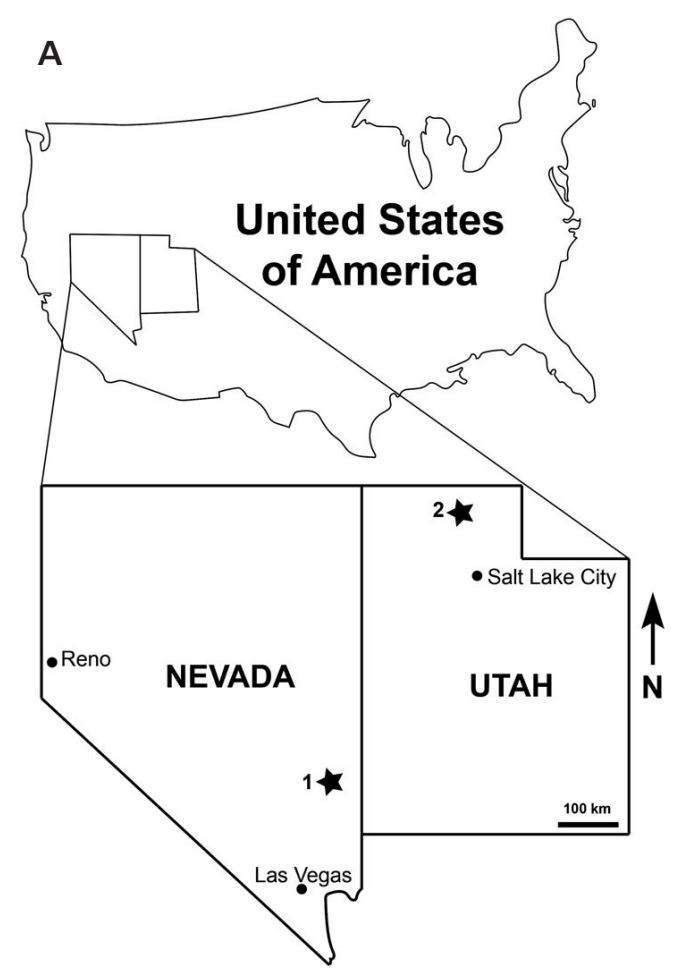

Lagerstätte of China (Lin et al. 2010), and the mid-Cambrian of Sweden (Eriksson \& Terfelt 2007). Despite this growing number of known fossilized coprolites in the Cambrian and the improved knowledge on digestive tracts and feeding habits of several Cambrian animals (Lerosey-Aubril et al. 2012, Vannier 2012, Vannier et al. 2014) it is often unclear what kind of animal(s) are the source of the coprolites. In most cases though, arthropods or worms are considered to be the producers (Mikulás 1995, Vannier \& Chen 2005, Shen et al. 2014).

This paper examines a variety of large coprolites from the late early to mid-Cambrian (Series 2-3) Pioche Formation and Spence Shale of Nevada and Utah. These coprolites occur together with BST soft-bodied fossils and are composed of carbonaceous flakes and films, skeletal debris and, for some Pioche Formation specimens, iron-bearing minerals (Lieberman 2003). Because the coprolites preserve skeletal debris, direct interpretation of predator-prey relationships is possible, as both predator and prey can potentially be identified. Specimens consisting only of carbonaceous films provide some information on the lifestyle of the predator and the preservation of the coprolites in burrows allows the identification of possible producers, by reducing the pool of potential source organisms. As there is some cross-over between the biota of the Pioche Formation/Spence Shale biota and the biotas found in other Cambrian BSTs (Robison et al. 2015), these results have broader implications for the interpretation and understanding of coprolites from Cambrian BST deposits.

\section{Geological setting}

The coprolites described herein are from the early to mid-Cambrian (Series 2-3, upper Olenellus to Eokochaspis biozones) Comet Shale Member (Lieberman 2003) of the Pioche Formation in Nevada and the mid-Cambrian (Series 3, Glossopleura Biozone) Spence Shale Member of the Langston Formation in Utah (Fig. 1; Liddell et al. 1997). Both deposits were likely seaward of a carbonate platform that subsequently planed off and formed part of the fine-grained middle carbonate or outer detrital belt of the Great basin (Robison 1991, Liddell et al. 1997, Lieberman 2003).

The Pioche Formation is a deeper water slope deposit, which is separated into six members. At least two horizons containing BST fossils are found in the Comet Shale Member. The first horizon is early Cambrian in age and the second horizon is mid-Cambrian (Moore \& Lieberman 2009). The Comet Shale biota is arthropod dominated, including species of olenelloid and ptychoparid trilobites, the carapaced arthropods Canadaspis, ?Perspicaris, and Tuzoia, and at least two species of Anomalocaris (Lieberman 2003). In addition to arthropods, the priapulid worm Ottoia, brachiopods, sponges, hyolithids, gastropods, and eocrinoids are also found. Soft-bodied animals are relatively rare. Olenelloid trilobites are common in the Series 2 parts of the shale, and the ptychoparioid trilobites are common in the Series 3 parts (Lieberman 2003, Webster et al. 2008, Moore \& Lieberman 2009). 

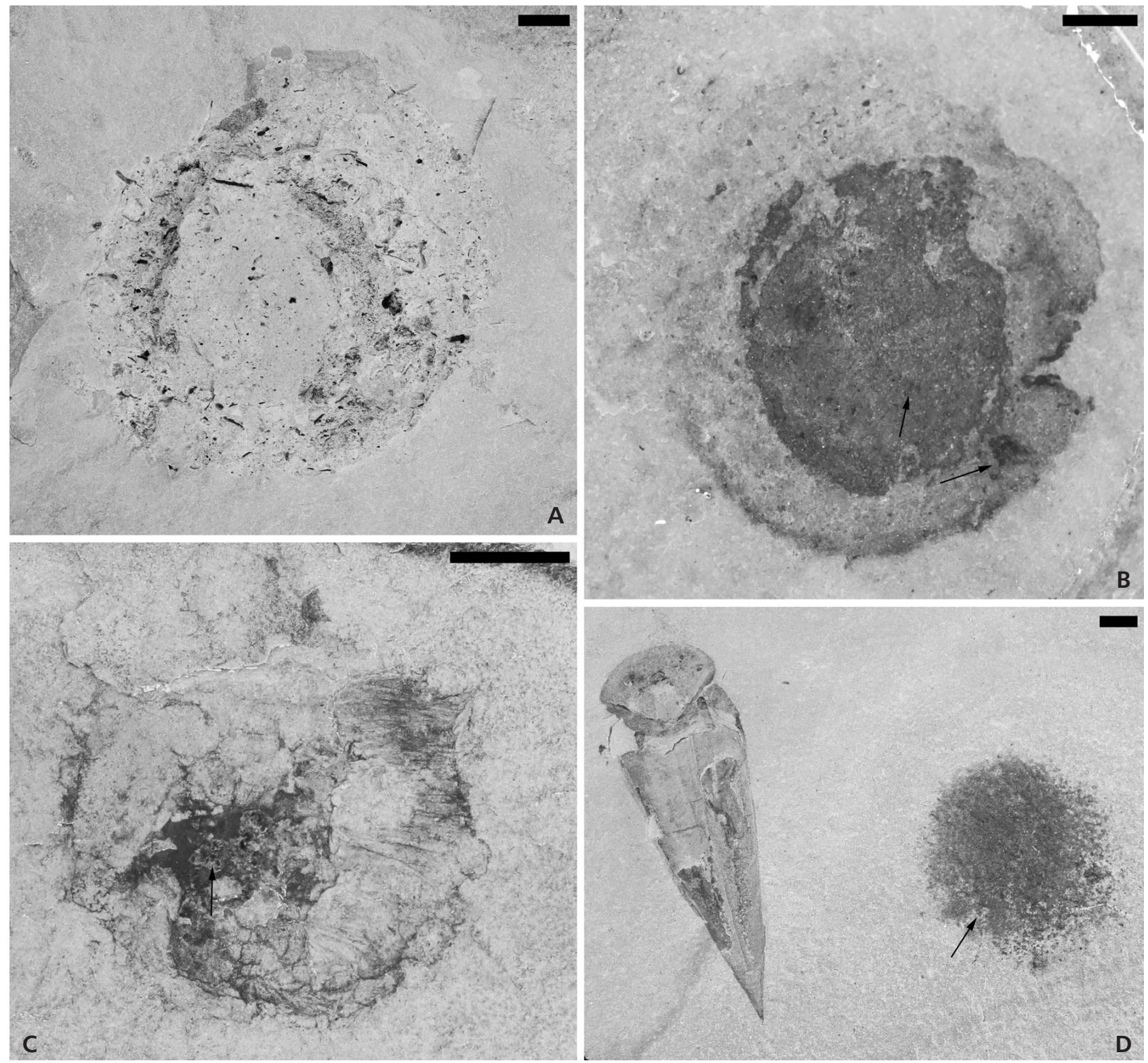

Figure 2. Round disk-shaped coprolites of Morphotype 1. • A - KUMIP 204369 large specimen preserving skeletal fragments. • B - KUMIP 377080 dense aggregate preserving a carbonaceous halo. $\bullet$ C - KUMIP 314126 dense aggregate preserving worm cuticle. $\bullet$ D - KUMIP 314260 dense aggregate with a specimen of Haplophrentis reesei on the same slab. Scale bars are $5 \mathrm{~mm}$. Arrows indicate pellets.

The Spence Shale is a regionally extensive deeper water slope deposit found in southeastern Idaho and northeastern Utah (Fig. 1; Liddell et al. 1997). The BST fossils occur in several meter-thick calcareous mudstones, and are most abundant on the western flank of the Wellsville Mountains near Brigham City, Utah (Liddell et al. 1997, Briggs et al. 2008). The Spence Shale biota is one of the more diverse BST biotas and has yielded a wide array of carapaced arthopods, great appendage arthropods, annelid and priapulid worms, hyoliths, brachiopods, sponges, algae and stem group metazoans (Rigby 1983, Briggs et al. 2008,
Conway Morris et al. 2015, Kimmig \& Pratt 2015, Legg \& Pates 2017, Kimmig et al. in press).

The Spence Shale preserves a diverse ichno fauna of at least 19 species (Hammersburg et al. 2013) and the ichnofabric index varies between 1 and 4 through the exposure, with a majority of the layers having an ichnofabric index of 1 (Garson et al. 2012; Kloss et al. 2015a, b). While most of the traces found in the Spence Shale are shallow burrows, they co-occur with soft-bodied fossils (Garson $e t$ al. 2012), and some deeper vertical burrows are also present and play an important role in the preservation of the 
Table 1. Locality information and size of specimens analyzed in this study. Chief Range is located at $37^{\circ} 42^{\prime} \mathrm{N}, 114^{\circ} 33^{\prime} \mathrm{W}, \mathrm{Highland}$ Range is located at $37^{\circ} 53^{\prime} \mathrm{N}, 114^{\circ} 34^{\prime} \mathrm{W}$ and the Miner's Hollow locality in the Wellsville Mountains is located at $41^{\circ} 36^{\prime} \mathrm{N}, 112^{\circ} 02^{\prime} \mathrm{W}$.

\begin{tabular}{|c|c|c|c|c|c|c|}
\hline Specimen ID & Morphotype & Locality & Lithostratigraphy & length $(\mathrm{mm})$ & width $(\mathrm{mm})$ & depth $(\mathrm{mm})$ \\
\hline KUMIP 377064 & 1 & Wellsville Mountains, Box Elder Co, Utah & Spence Shale Mb., Langston Fm. & 13 & 12 & 3 \\
\hline KUMIP 204368 & 1 & Wellsville Mountains, Box Elder Co, Utah & Spence Shale Mb., Langston Fm. & 29 & 25 & 9 \\
\hline KUMIP 204369 & 1 & Wellsville Mountains, Box Elder Co, Utah & Spence Shale Mb., Langston Fm. & 42 & 40 & 1 \\
\hline KUMIP 314124 & 1 & Unrecorded & Spence Shale Mb., Langston Fm. & 21 & 20 & 1 \\
\hline KUMIP 314126 & 1 & Wellsville Mountains, Box Elder Co, Utah & Spence Shale Mb., Langston Fm. & 20 & 19 & 0.5 \\
\hline KUMIP 314260 & 1 & Wellsville Mountains, Box Elder Co, Utah & Spence Shale Mb., Langston Fm. & 20 & 21 & 0.5 \\
\hline KUMIP 376843 & 1 & Wellsville Mountains, Box Elder Co, Utah & Spence Shale Mb., Langston Fm. & 20 & 19 & 2 \\
\hline KUMIP 376844 & 1 & Wellsville Mountains, Box Elder Co, Utah & Spence Shale Mb., Langston Fm. & 25 & 24 & 6 \\
\hline KUMIP 376845 & 1 & Wellsville Mountains, Box Elder Co, Utah & Spence Shale Mb., Langston Fm. & 30 & 27 & 7 \\
\hline KUMIP 376846 & 1 & Wellsville Mountains, Box Elder Co, Utah & Spence Shale Mb., Langston Fm. & 17 & 17 & 10 \\
\hline KUMIP 376847 & 1 & Wellsville Mountains, Box Elder Co, Utah & Spence Shale Mb., Langston Fm. & 20 & 20 & 5 \\
\hline KUMIP 376848 & 1 & Wellsville Mountains, Box Elder Co, Utah & Spence Shale Mb., Langston Fm. & 18 & 16 & 8 \\
\hline KUMIP 376849 & 1 & Wellsville Mountains, Box Elder Co, Utah & Spence Shale Mb., Langston Fm. & 24 & 20 & 9 \\
\hline KUMIP 376849 & 1 & Wellsville Mountains, Box Elder Co, Utah & Spence Shale Mb., Langston Fm. & 23 & 22 & 8 \\
\hline KUMIP 376850 & 1 & Wellsville Mountains, Box Elder Co, Utah & Spence Shale Mb., Langston Fm. & 29 & 27 & 10 \\
\hline KUMIP 376851 & 1 & Wellsville Mountains, Box Elder Co, Utah & Spence Shale Mb., Langston Fm. & 22 & 21 & 10 \\
\hline KUMIP 377066 & 1 & Wellsville Mountains, Box Elder Co, Utah & Spence Shale Mb., Langston Fm. & 15 & 14 & 2 \\
\hline KUMIP 377077 & 1 & Wellsville Mountains, Box Elder Co, Utah & Spence Shale Mb., Langston Fm. & 25 & 19 & 5 \\
\hline KUMIP 377078 & 1 & Wellsville Mountains, Box Elder Co, Utah & Spence Shale Mb., Langston Fm. & 25 & 20 & 2 \\
\hline KUMIP 377080 & 1 & Wellsville Mountains, Box Elder Co, Utah & Spence Shale Mb., Langston Fm. & 22 & 20 & 0.5 \\
\hline KUMIP 419284 & 1 & Wellsville Mountains, Box Elder Co, Utah & Spence Shale Mb., Langston Fm. & 19 & 17 & 4 \\
\hline KUMIP 419285 & 1 & Wellsville Mountains, Box Elder Co, Utah & Spence Shale Mb., Langston Fm. & 15 & 7 & 6 \\
\hline KUMIP 314187 & 2 & Wellsville Mountains, Box Elder Co, Utah & Spence Shale Mb., Langston Fm. & 35 & 14 & 3 \\
\hline KUMIP 314195 & 2 & Wellsville Mountains, Box Elder Co, Utah & Spence Shale Mb., Langston Fm. & 25 & 5 & 1 \\
\hline KUMIP 377063 & 2 & Wellsville Mountains, Box Elder Co, Utah & Spence Shale Mb., Langston Fm. & 19 & 12 & 4 \\
\hline KUMIP 293610 & 2 & Chief Range, Lincoln Co, Nevada & Comet Shale Mb., Pioche Fm. & 30 & 7 & 1 \\
\hline KUMIP 378577 & 2 & Chief Range, Lincoln Co, Nevada & Comet Shale Mb., Pioche Fm. & 25 & 15 & 1 \\
\hline KUMIP 378576 & 3 & Highland Range, Lincoln Co, Nevada & Comet Shale Mb., Pioche Fm. & 36 & 12 & 1 \\
\hline KUMIP 314245 & 4 & Wellsville Mountains, Box Elder Co, Utah & Spence Shale Mb., Langston Fm. & 105 & 35 & 0.5 \\
\hline KUMIP 314255 & 4 & Wellsville Mountains, Box Elder Co, Utah & Spence Shale Mb., Langston Fm. & 70 & 10 & 0.5 \\
\hline KUMIP 366400 & 4 & Wellsville Mountains, Box Elder Co, Utah & Spence Shale Mb., Langston Fm. & 59 & 7 & 0.5 \\
\hline KUMIP 366401 & 4 & Wellsville Mountains, Box Elder Co, Utah & Spence Shale Mb., Langston Fm. & 78 & 9 & 0.5 \\
\hline KUMIP 377071 & 4 & Wellsville Mountains, Box Elder Co, Utah & Spence Shale Mb., Langston Fm. & 125 & 8 & 0.5 \\
\hline KUMIP 314243 & 5 & Wellsville Mountains, Box Elder Co, Utah & Spence Shale Mb., Langston Fm. & 130 & 7 & 1 \\
\hline KUMIP 377075 & 5 & Wellsville Mountains, Box Elder Co, Utah & Spence Shale Mb., Langston Fm. & 60 & 7 & 0.5 \\
\hline
\end{tabular}

coprolites in this deposit (this paper). The Pioche Formation preserves a variety of trace fossils (Moore \& Lieberman 2009), but no detailed studies on their systematics or co-occurrence with the soft-bodied fauna have been attempted to date.

\section{Material}

The described coprolites (Tab. 1) are all part of the University of Kansas, Biodiversity Institute, Division of Inverte- brate Paleontology collections (KUMIP). Pioche Formation specimens were collected between the 1980s and 1990s by the Gunther family, L.B. McCollum, and A.R. Palmer, at the Chief Range $\left(37^{\circ} 42^{\prime} \mathrm{N}, 114^{\circ} 33^{\prime} \mathrm{W}\right)$ and Highland Range $\left(37^{\circ} 53^{\prime} \mathrm{N}, 114^{\circ} 34^{\prime} \mathrm{W}\right)$ localities in Lincoln County, Nevada. Spence Shale specimens were collected between the 1970s and 1990s by the Gunther family, P. Rees, and R.A. Robison, at the Miner's Hollow locality $\left(41^{\circ} 36^{\prime} \mathrm{N}, 112^{\circ} 02^{\prime} \mathrm{W}\right)$ in the Wellsville Mountains, Box Elder County, Utah. Specimens were examined using a Leica S4E binocular microscope. All specimens were 

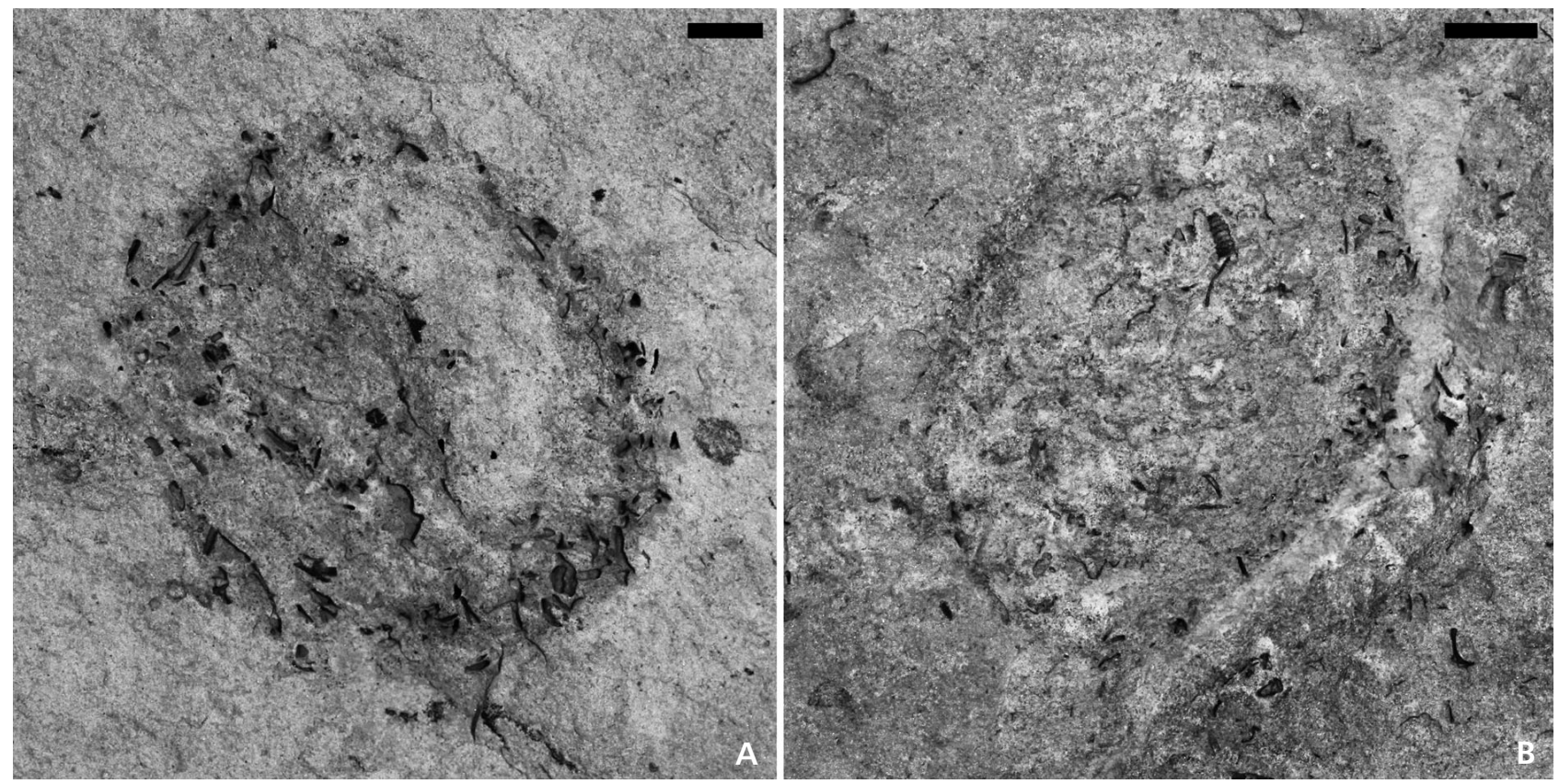

Figure 3. Round disk-shaped coprolite of Morphotype 1. A - KUMIP 204368 top of specimen preserving skeletal fragments and carbonaceous film. • B - KUMIP 204368 bottom of specimen preserving skeletal fragments and carbonaceous film. Scale bars are $5 \mathrm{~mm}$.

photographed using a Canon EOS 5D Mark II digital SLR camera equipped with a Canon $50 \mathrm{~mm}$ macro lens. Pictures were taken submerged in alcohol. The contrast, color and brightness of images were adjusted using Adobe Photoshop.

\section{Description}

\section{Coprolite morphotypes}

\section{Morphotype 1}

The most common coprolite in the Spence Shale is represented by 22 specimens (Spence: KUMIP 204368, 204369, 314124, 314126, 314260, 376844-376851, 377064, 377066, 377077, 377078, 377080, 419284, 419285). Each consists of a round to ellipsoid organic accumulation, ranging from $13 \mathrm{~mm}$ to $42 \mathrm{~mm}$ in diameter. These have sharp edges and consist of variably dense aggregates composed of up to hundreds of carbonaceous flakes, sometimes with additional worm cuticle, trilobite parts, and/or possible shell fragments (Figs 2A-D, 3A, B, 4A-F). The pellets can be discriminated in the less dense aggregates, where they are dorso-ventrally ovoid to ellipsoid in outline and $\sim 0.5 \mathrm{~mm}$. The length-to-width ratio varies between $\sim 1: 1$ to $2: 1$, variably creating round to ellipsoid pellets. Some aggregates preserve relief up to $3 \mathrm{~mm}$, and six specimens (KUMIP 204368, 376844, 376845, 376848, 376851, 377066) are large enough to be visible on both sides of their source slab (Figs 3A, B, 4A-F). The thickest coprolites are $10 \mathrm{~mm}$ (KUMIP 204368), but the majority range from $<1 \mathrm{~mm}$ to $2 \mathrm{~mm}$ in size. KUMIP 377080 preserves a $1 \mathrm{~mm}$ wide diffuse carbonaceous halo about $2 \mathrm{~mm}$ from the edge of the inner margin.

Trilobite, brachiopod, and possible eocrinoid (KUMIP 204368 and 204369, Conway Morris \& Robison 1988) fragments are preserved in some of the coprolites, and one (KUMIP 314126) also contains worm cuticles. The fossils are always matrix/pellet supported and make up less than $10 \%$ of the actual composition of the coprolites. None of the identifiable fossil material appears to be complete.

\section{Morphotype 2}

Five specimens (Spence: KUMIP 314187, 314195, 377063, Pioche: KUMIP 293610, 378577) of elongated, ellipsoid coprolites $19 \mathrm{~mm}$ to $35 \mathrm{~mm}$ in length and $5 \mathrm{~mm}$ to $15 \mathrm{~mm}$ wide (Fig. 5A-C). All specimens are preserved on the surface of slabs, have sharp, well-defined edges, and consist of round to ellipsoid pellets of about $0.5 \mathrm{~mm}$ to $2 \mathrm{~mm}$ in diameter. The maximum thickness is $4 \mathrm{~mm}$.

\section{Morphotype 3}

One elongated, ellipsoid coprolite (Pioche: KUMIP 378576, Fig. 6) composed of unidentifiable skeletal fragments. It is $36 \mathrm{~mm}$ long and $12 \mathrm{~mm}$ wide. It has no soft-tissue preserved. 


\section{Morphotype 4}

Five specimens (Spence: KUMIP 314245, 314255, $366400,366401,377071)$ of pellet-filled burrows (Fig. 7A-C). The pellets are elongate, vary from straight to curved, range from $2 \mathrm{~mm}$ to $125 \mathrm{~mm}$ in length, and are about $0.5 \mathrm{~mm}$ to $1 \mathrm{~mm}$ wide. The pellets are aligned parallel to the direction of the burrow and sometimes overlay each other. The wall of the burrow is smooth. The burrows are $59 \mathrm{~mm}$ to $105 \mathrm{~mm}$ long and between $7 \mathrm{~mm}$ and 35 wide. The widest part consists of a chamber-like structure at the end of the burrow. Branching is observed twice in KUMIP 314245 (Fig. 7A) and once in KUMIP 366401 (Fig. 7B). The other three specimens do not show any signs of branching.

\section{Morphotype 5}

Two specimens (Spence: KUMIP 314243, 377075) representing filled burrows with round pellets (Fig. 7D). The burrows are $60 \mathrm{~mm}$ to $130 \mathrm{~mm}$ long and $7 \mathrm{~mm}$ wide. The wall of the burrow is smooth. No branching is observed in Morphotype 5 burrows. One of the Morphotype 5 burrows (KUMIP 314243) preserves fragments of trilobites, agnostoids, and hyoliths. The fragments range from $2 \mathrm{~mm}$ to $7 \mathrm{~mm}$ in size and are pellet supported.

\section{Associated faunas}

Most of the coprolites are isolated specimens, with no animals represented on the same slab. Two specimens (KUMIP 293610, 314260) have hyoliths associated with them, two specimens (KUMIP 377063, 377071) have agnostoids and trilobites on the same slab, and one specimen (KUMIP 314187) preserves a lingulid brachiopod. The hyoliths were likely not part of the coprolites, as they are not in close proximity and are too large by comparison (Figs 2D, 5B). The agnostoids and trilobites are also entirely separate from the coprolites and in KUMIP 377071 they are articulated, and thus were likely not digested. The lingulid brachiopod is in the center of the coprolite (Fig. 5C) and is a complete valve. This brachiopod likely represents a digested specimen. Because it is complete, the source predator for the associated coprolite was probably not a shell-crushing predator and could potentially only dissolve soft-tissue.

\section{Discussion}

\section{Coprolite origin and producers}

The large size, circular shape and organic composition of the Great Basin Morphotype 1 coprolites suggest that the original feces were likely deposited in a burrow, with the circular outline of the coprolite due to the shape of the burrow and not due to compression of a fecal ball. In some cases, the burrows can be observed on both sides of the rock slab. In three cases, this represents a distance of $10 \mathrm{~mm}$. Considering the putative $85 \%$ compaction rate for BST deposits (Whittington 1985), this would indicate an original length of the burrow of at least $85 \mathrm{~mm}$. Similar observations have been made in the Ravens Throat River Lagerstätte, where coprolites preserve spreiten structures (unpublished observation). It is unlikely that the structures represent poorly preserved jellyfish, eldonids, or Ediacaran-like discoidal fossils, as no rays, ridges, or circular structures are preserved; typical features of such fossils (Liu et al. 2015, Lieberman et al. 2017, McMahon et al. 2017, Sappenfield et al. 2017).

The common hypothesis is that coprolites of the kind found in the Great Basin were produced by large predators or scavengers (Mikuláš 1995, Blau et al. 1997, English \& Babcock 2010). However, a study of modern worms by Schäfer (1953) suggests either priapulids or large annelids were the potential producers. Schäfer (1953) demonstrated that worms are able to form both isolated pellets and piles of pellets which, when compacted, would form structures similar to the round to ellipsoid specimens typical of Morphotype 1. Alternatively, many round invertebrate coprolites have been previously attributed to crustaceans (Blau et al. 1997, Schweigert et al. 1997, Senowbari-Daryan \& Kube 2003). Large stem group arthropods such as Anomalocaris and Tuzoia are part of the Great Basin biota and, therefore, could also be the source of Morphotype 1.

The length of at least $85 \mathrm{~mm}$ in some of the Morphotype 1 burrows, together with the relatively rare horizontal burrows in both the Pioche and the Spence, indicate the environment in the Great Basin during the Cambrian might have, at times, been well oxygenated and allowed for bioturbation at a larger scale than in some other BST deposits (Garson et al. 2012, Kimmig \& Pratt 2016). However, it is also possible that individualistic taphonomic or diagenetic pathways present in other BST deposits did not allow for the preservation of the kinds of burrows found in the Great Basin deposits.

The producer of Morphotype 2 was a predator or scavenger that hunted soft-bodied animals, as the specimens are elongated coprolites composed of soft tissue pellets with no skeletal remains. Morphotype 2 has no relief, suggesting that the producer lived on the seafloor or in the water column. Considering the large size of Morphotype 2 (19 to $35 \mathrm{~mm}$ ) and, given the known animals in the Great Basin Cambrian biota capable of producing a coprolite of that size, a larger arthropod is the only possible progenitor. It could possibly have been derived from one of the anomalocaridids known from both the Pioche and the 

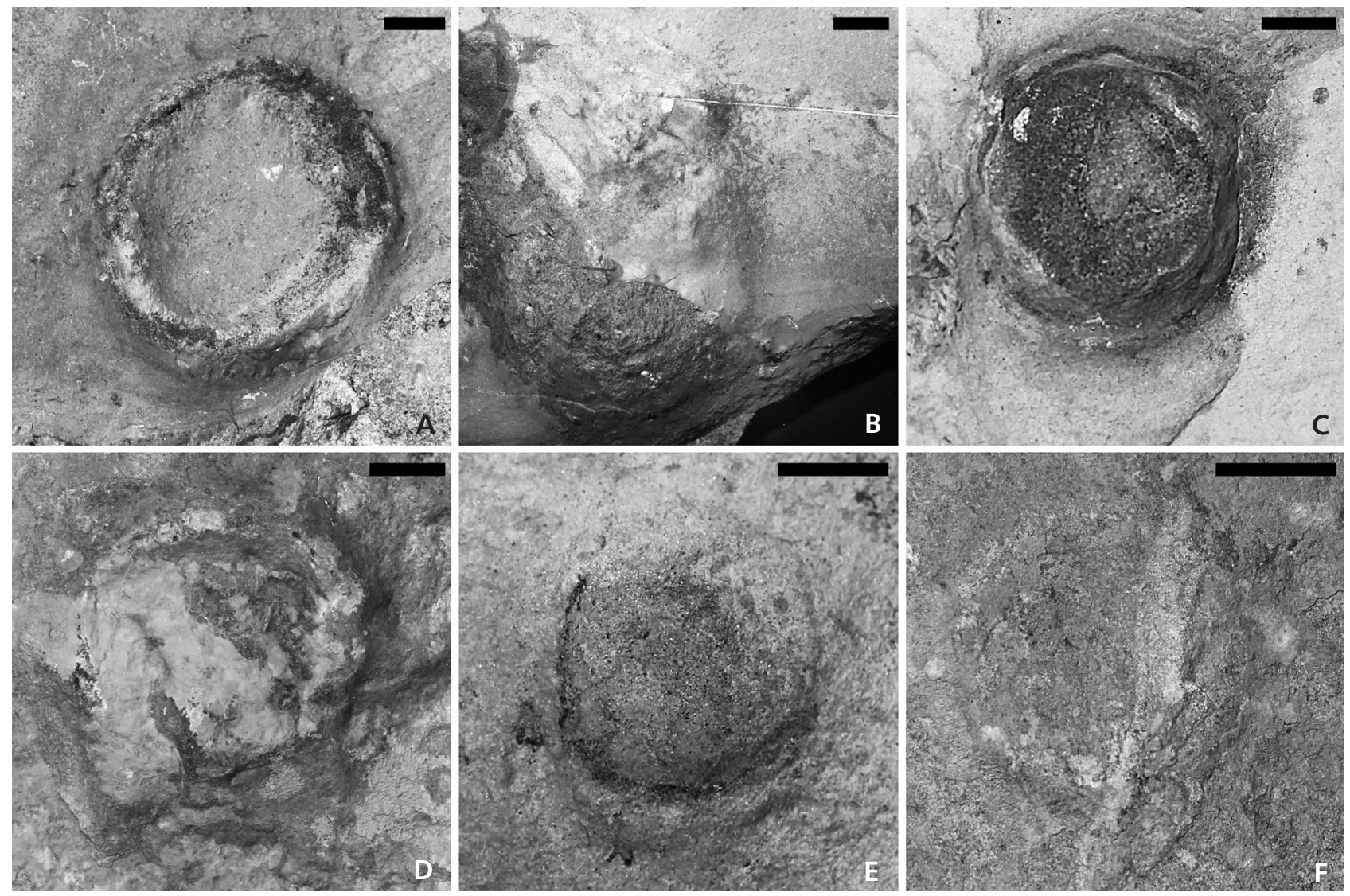

Figure 4. Round carbonaceous disk-shaped coprolites of Morphotype 1 apparent on both sides of the slab. • A - KUMIP 376845 top view, preserving carbonaceous flakes and negative relief. $\bullet$ B - KUMIP 376845 bottom view, preserving carbonaceous film and positive relief. $\bullet$ C - KUMIP 376844 top view, preserving carbonaceous flakes and positive relief. $\bullet$ D - KUMIP 376844 bottom view, preserving carbonaceous film fragments and positive relief. - E - KUMIP 419285 top view, preserving carbonaceous flakes and positive relief. $\bullet$ F - KUMIP 419285 bottom view, preserving positive relief. Scale bars are $5 \mathrm{~mm}$.

Spence, as previous work has determined that some anomalocaridids only fed on soft-bodied animals (Daley et al. 2013).

Either a predator or a scavenger must have been the source of Morphotype 3. The dense accumulation of agnostoid and other skeletal fragments indicates that the producer was able to digest most soft tissue associated with the prey and that it was likely their main food source, as omnivores usually produce a coprolite composed of a mix of sediment, organic matter, and exoskeletal fragments (Vannier \& Chen 2005, Zacaï et al. 2016, Peel 2017). The coprolite shows similarities to the ellipsoid aggregates described from the Maotianshan Shale, which have been attributed to large arthropods (Vannier \& Chen 2005), consistent with our predator/scavenger interpretation. A possible producer might be Tuzoia, as it has been linked with predation on trilobites in the Jince Formation of the Czech Republic (Fatka et al. 2015).

Morphotype 4 likely represents specimens of the ichnogenus Tomaculum Groom, 1902. The long slim pellets in the burrows, the curvature, and the arrangement of the pellets all correspond to the description of the ichnogenus (Eiserhardt et al. 2001). Morphotype 4 differs from the type description in two key ways. Firstly, no individual fecal pellets can be observed in the elongated organic structures. Secondly, Morphotype 4 specimens KUMIP 314245 and 366401 are branched. Eiserhardt et al. (2001) mentioned that Tomaculum specimens were likely not produced by worms, as studies on modern worms showed that they are not able to produce the kind of elongated ribbon-like pellet accumulations found in Tomaculum. If this was also the case for Cambrian worms, then the burrows were likely created by arthropods, this might also explain the presence of arthropod and hyolith fragments in one Morphotype 4 specimen. Cambrian trace fossils indicate that trilobites might have been predatory (Tarhan et al. 2011, Selly et al. 2016) and the size of the burrows associated with Morphotype 4, accounting for compaction, could have housed a variety of different trilobite species. Some bradoriids and other carapaced arthropods would also fit the size of the burrows. Alternatively, palaeoscolid worms do co-occur with Tomaculum-like 

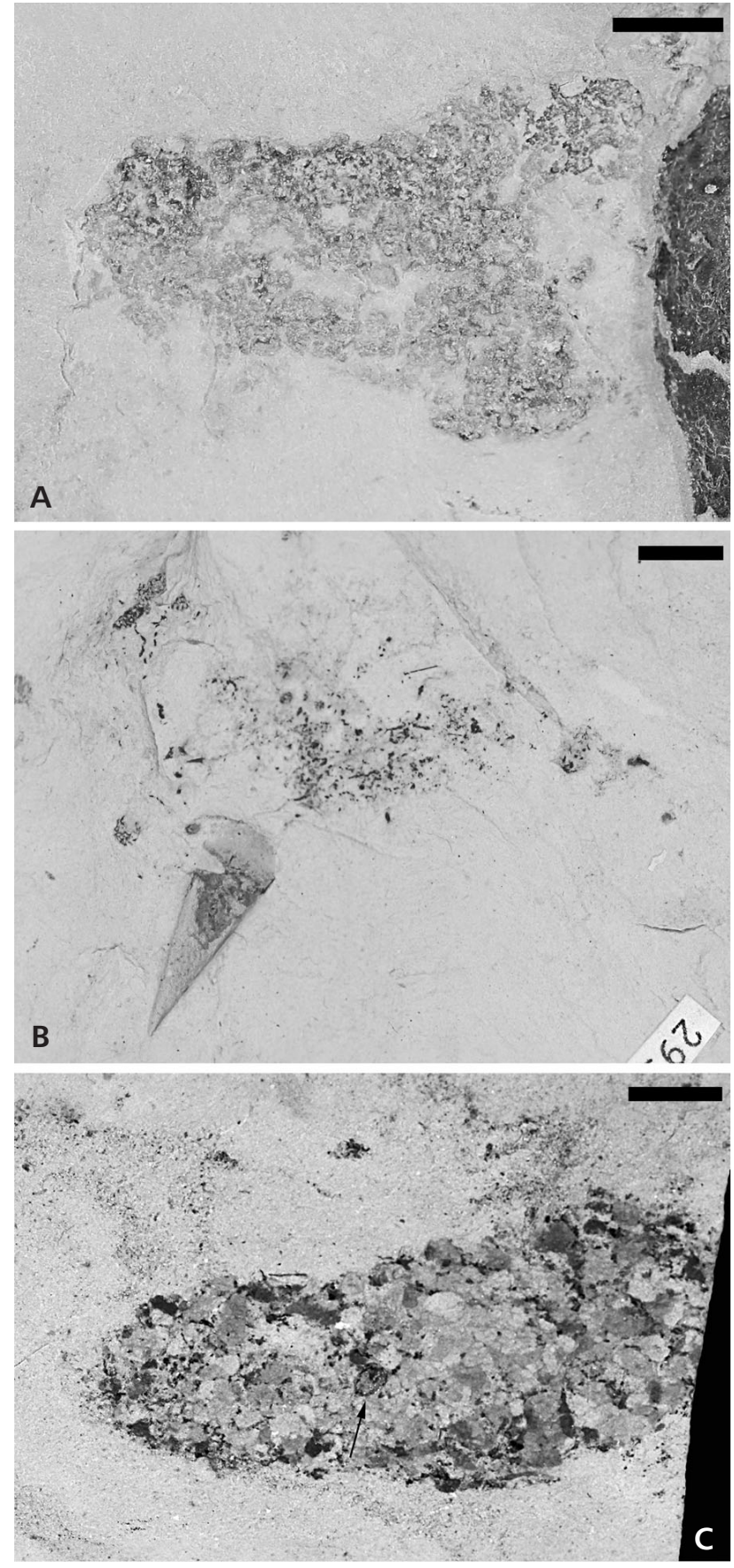

Figure 5. Coprolites of Morphotype 2. • A - KUMIP 378577, elongated coprolite preserving ellipsoid pellets. • B - KUMIP 293610 dispersed elongated coprolite in association with hyolith, with preserved operculum. • C - KUMIP 314187 elongated coprolite in association with a lingulid brachiopod (arrow). Scale bars are $5 \mathrm{~mm}$.

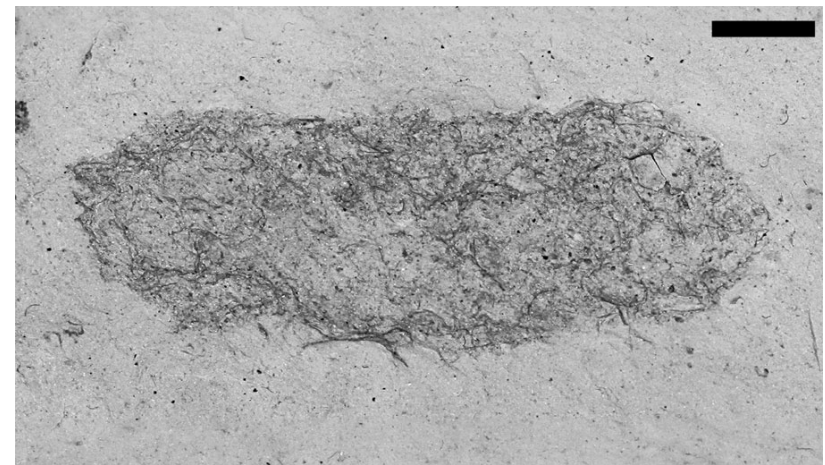

Figure 6. Coprolite of Morphotype 3 (KUMIP 378576): elongated coprolite preserving fragmentary agnostids and skeletal debris. Photographed under alcohol. Scale bar is $5 \mathrm{~mm}$.

structures in the Ordovician Fezouata Lagerstätte in Morocco, indicating a worm could have produced the pellet-filled burrows in this deposit (Martin et al. 2016).

Morphotype 5 specimens are tentatively attributed to the ichnogenus Planolites? Nicholson, 1873, based on the smooth walls, the round pellets which fill the burrow, and because no branching is observed in the specimens. The producers of the burrows were likely a range of different worm species (Valentine 1995, Marenco \& Bottjer 2008). The presence of priapulids and other worms in the Pioche and Spence (Robison 1969, Conway Morris \& Robison 1986, Lieberman 2003) supports this interpretation.

\section{Comparison to other Cambrian coprolites}

Invertebrate coprolites have a sparse record in the Paleozoic (English \& Babcock 2010, Eriksson et al. 2011, Slater et al. 2012, Fiorelli et al. 2013). Round and elongated coprolites are found in marine and terrestrial environments of the Paleozoic and have been ascribed to a wide variety of producers. In the early Paleozoic they are usually attributed to large arthropods (Conway Morris \& Robison 1988, English and Babcock 2010), as these are considered to have been alpha predators.

Round coprolites, similar in shape and size to the ones described herein have also been reported from the Lower Cambrian Paseky Shale in the Czech Republic (Mikuláš 1995). Similar to the Pioche and Spence coprolites, they are variably filled with arthropod fragments and round to oval pellets. Mikuláš (1995) argued that the coprolites were likely produced by large arthropods, but he did not

Figure 7. Pellet-filled burrows. • A - KUMIP 314245, coprolite of Morphotype 4, Tomaculum? burrow filled with elongated pellets and 2 branches. - B - KUMIP 366401 coprolite of Morphotype 4, Tomaculum? burrow filled with elongated pellets and 1 probable branch. $\bullet$ C - KUMIP 314255 coprolite of Morphotype 4, Tomaculum? burrow filled with elongated pellets and 1 probable branch. $\bullet$ D - KUMIP 377075, coprolite of Morphotype 5, Planolites? burrow filled with round to ellipsoid pellets. Scale bars are $5 \mathrm{~mm}$. 

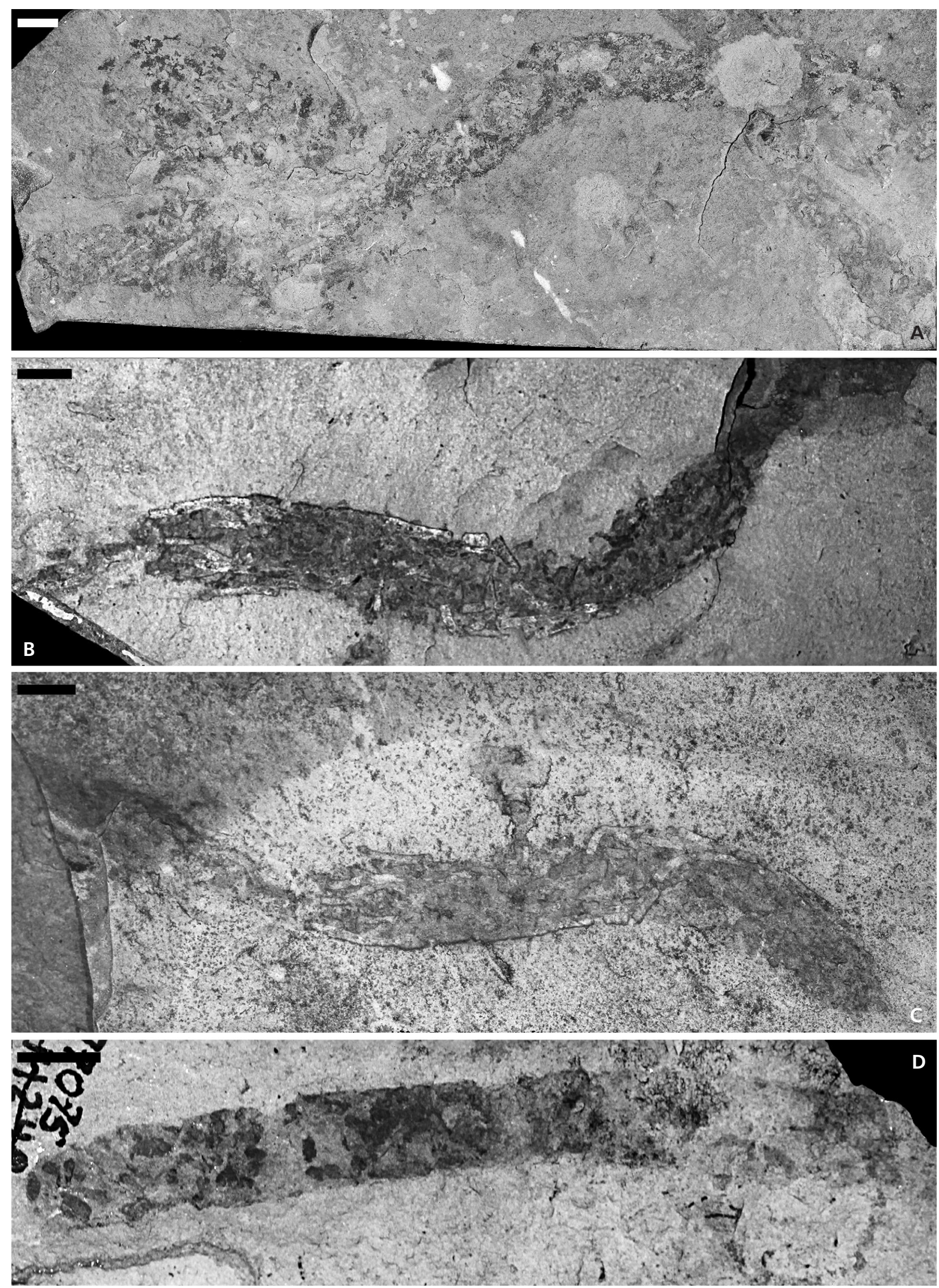
name any specific producers. It is unclear if those coprolites were deposited in burrows or on the seafloor. However, as many of the coprolites in the Spence Shale inferred to have been produced in burrows are similar in appearance to those in the Paseky Shale, it is perhaps possible that those from the Paseky were also produced in burrows. This would explain their circular outline. If this is the case they would have had to be deposited in shallow burrows, as the Paseky Shale only preserves shallow bioturbation (Mikuláš, personal communication).

Coprolites that have been previously reported from BST deposits (Nedin 1999, Vannier \& Chen 2005, English \& Babcock 2010, Lin et al. 2010) are usually rich in animal fragments and ellipsoid to elongate in shape (Vannier \& Chen 2005, English \& Babcock 2010). These coprolites are generally attributed to large arthropods or priapulids, but there has been little evidence provided to support these assertions. With few body fossils directly associated with the Pioche and Spence coprolite specimens, our interpretation of possible producers is based on modern analogues and the known fossil record of the source deposits. Priapulids or other worms are a likely producer for many of the Morphotype 1 coprolites in the Pioche and the Spence, as modern relatives are known to dig burrows if the substrate is muddy (Vannier et al. 2010, Vannier \& Martin 2017), and predatory behavior has been observed in some modern burrowing worms (Lachat \& Haag-Wackernagel 2016). Specimens of the priapulid Ottoia prolifica from the Burgess Shale preserve guts containing exoskeletal fragments, notably hyolith conches, arthropods, and brachiopod valves. The skeletal elements in the Burgess Shale Ottoia specimens are filled with sediment and ribbon-like features, indicating that Ottoia was an omnivore (Vannier 2012). Other potential vermiform coprolite producers could be palaeoscolecids. Cambrian palaeoscolecid species were mostly deposit feeders (Martin et al. 2016) but some also fed on organic matter, as arthropod remains have been preserved in at least one specimen from Sirius Passet (Conway Morris \& Peel 2010).

Trilobites are another possible producer, as they are known to be able to burrow and some species have been identified as potential predators, but their feeding strategies are poorly understood (Chatterton et al. 1994, Fortey \& Owens 1999, Hughes 2001, Lerosey-Aubril et al. 2011, Tarhan et al. 2011, Selly et al. 2016). Because the burrows in the Pioche and Spence Shale deposits do not preserve any scratch marks, as would be expected for trilobites (Seilacher 2007), it is more likely that worms or other arthropods are the source of the burrows. It is also possible that the fine-grained mudstones did not preserve the scratch marks.

The fecal pellet-filled burrows of Morphotypes 4 and 5 are comparable to structures found throughout the Phanerozoic (Robison 1969, Eiserhardt et al. 2001, Marenco
\& Bottjer 2008, Buatois \& Mángano 2011). These structures have been attributed to a range of producers, including several kinds of arthropods, worms and gastropods (Schäfer 1953, Pickerill \& Narbonne 1995, Eiserhardt et al. 2001). Similar burrows can be found in other BST deposits, for example, the Wulongqing Formation of the early Cambrian of China (Hu et al. 2010, Weber et al. 2012) and the mid-Cambrian Kaili biota (Lin et al. 2010).

Microscopic coprolites have been described from the Cambrian of China (Shen et al. 2014) and Greenland (Peel 2015). In both cases the producers are not known, but brachiopods or mollusks have been suggested. Considering the size and shape of the coprolites from those deposits differ markedly from the Pioche and Spence coprolites, it is unlikely that they have a common provenance.

\section{Conclusions}

The relatively rare coprolites in the Pioche Formation and Spence Shale provide information about the enigmatic food chain of the mid-Cambrian. The intact coprolites we assign to Morphotype 1 are typically around $20 \mathrm{~mm}$ in size and were likely produced by one or a few closely related species of predators that inhabited burrows in which the fecal pellets were accumulated. Considering coprolites of similar size, shape, and composition from other deposits, as well as the animals that have been recovered in the Pioche Formation and the Spence Shale, it is likely that the producer was a burrowing arthropod or priapulid. Larger animals living on the sediment or in the water column likely produced the coprolites we assign to Morphotypes 2 and 3. Smaller animals produced the pellet-filled burrows of Morphotype 4 and 5. Considering the shape of the fecal matter, as well as comparable traces in the Paleozoic, they were likely produced by worms or possibly trilobites.

\section{Acknowledgments}

Thanks to Brian Pratt for valuable discussion on Cambrian coprolites. Thanks to Bruce S. Lieberman for comments on earlier versions of the manuscript. We also thank the referees Sören Jensen and Radek Mikuláš and the handling Editor for suggestions that improved the manuscript.

\section{References}

Aldridge, R.J., Gabbott, S.E., Siveter, L.J. \& Theron, J.N. 2006. Bromalites from the Soom Shale Lagerstätte (Upper Ordovician) of South Africa: palaeoecological and palaeobiological implications. Palaeontology 49, 857-871.

DOI 10.1111/j.1475-4983.2006.00570.x 
Bengtson, S. 2002. Origins and early evolution of predation. Paleontological Society Papers 8, 289-317.

Blau, J., GrüN, B. \& JAGT, J.W.M. 1997. New Maastrichtian crustacean microcoprolites from the Maastrichtian type area. Neues Jahrbuch für Geologie und Paläontologie, Monatshefte 1997, 1-11.

Briggs, D.E.G., Lieberman, B.S., Hendricks, J.R., Halgedahl, S.L. \& JARRARD, R.D. 2008. Middle Cambrian arthropods from Utah. Journal of Paleontology 82, 238-254. DOI 10.1666/06-086.1

Buatois, L.A. \& Mángano, M.G. 2011. Ichnology. Organism-Substrate Interactions in Space and Time. 358 pp. Cambridge University Press, Cambridge. DOI 10.1017/CBO9780511975622

BuDD, G.E. 2013. At the origin of animals: the revolutionary Cambrian fossil record. Current Genomics 14, 344-354. DOI 10.2174/13892029113149990011

Chatterton, B.D.E., Johanson, Z. \& Sutherland, G. 1994. Form of the trilobite digestive system: Alimentary structures in Pterocephalia. Journal of Paleontology 69, 294-305. DOI 10.1017/S0022336000022897

CHEN, M. \& CHEN, Y. 1980. Note on a possible coprolites from the lowest Cambrian strata of Yangtze Gorge. Scientia Geologica Sinica 10, 406-407.

Conway Morris, S. \& Peel, J.S. 2010. New palaeoscolecidan worms from the Lower Cambrian: Sirius Passet, Latham Shale and Kinzers Shale. Acta Palaeontologica Polonica 55, 141-156. DOI 10.4202/app.2009.0058

Conway Morris, S. \& Robison, R.A. 1986. Middle Cambrian priapulids and other soft-bodied fossils from Utah and Spain. The University of Kansas Paleontological Contributions 117, $1-22$.

Conway Morris, S. \& Robison, R.A. 1988. More soft-bodied animals and algae from the Middle Cambrian of Utah and British Columbia. The University of Kansas Paleontological Contributions 122, 1-48.

Conway Morris, S., Selden, P.A., Gunther, G., Jamison, P.G. \& Robison, R.A. 2015. New records of Burgess Shale-type taxa from the middle Cambrian of Utah. Journal of Paleontology 89, 411-423. DOI 10.1017/jpa.2015.26

Daley, A.C., Patterson, J.R., Edgecombe, G.D., GarcíaBELLido, D.C. \& JAGO, J.B. 2013. New anatomical information on Anomalocaris from the Cambrian Emu Bay Shale of South Australia and a reassessment of its inferred predatory habits. Palaeontology 56, 971-990.

Eiserhardt, K.H., Koch, L. \& EISERHARDT, W.L. 2001. Revision des ichnotaxon Tomaculum Groom, 1902. Neues Jahrbuch für Geologie und Paläontologie, Abhandlungen 221, 235-358.

English, A.M. \& BAвCOCK, L.E. 2010. Census of the Indian Springs Lagerstätte, Poleta Formation (Cambrian), western Nevada, USA. Palaeogeography, Palaeoclimatology, Palaeoecology 295, 236-244.

DOI 10.1016/j.palaeo.2010.05.041

Eriksson, M.E. \& Terfelt, F. 2007. Anomalous facies and ancient faeces in the latest middle Cambrian of Sweden. Lethaia 40, 69-84. DOI 10.1111/j.1502-3931.2006.00007.x
Eriksson, M.E., Lindgren, J., Chin, K. \& MÅnsby, U. 2011. Coprolite morphotypes from the Upper Cretaceous of Sweden: novel views on an ancient ecosystem and implications for coprolite taphonomy. Lethaia 44, 455-468. DOI 10.1111/j.1502-3931.2010.00257.x

FatKa, O., Budil, P. \& Grigar, L. 2015. A unique case of healed injury in a Cambrian trilobite. Annales de Paléontologie 101, 295-299. DOI 10.1016/j.annpal.2015.10.001

Fiorelli, L.E., Ezcurra, M.D., Hechenleitner, E.M., ArgañaRAZ, E., TABORda, J.R.A., TrotTEYn, M.J., BACZKo, M.B. von \& Desojo, J.B. 2013. The oldest known communal latrines provide evidence of gregarism in Triassic megaherbivores. Scientific Reports 3, 3348. DOI 10.1038/srep03348

Fortey, R.A. \& Owens, R.M. 1999. Feeding habits in trilobites. Palaeontology 42, 429-465. DOI 10.1111/1475-4983.00080

Garson, D.E., Gaines, R.R., Droser, M.L., Liddell, W.D. \& SAPPENFIELD, A. 2012. Dynamic palaeoredox and exceptional preservation in the Cambrian Spence Shale of Utah. Lethaia 45, 164-177.

DOI 10.1111/j.1502-3931.2011.00266.x

Groom, T. 1902. The sequence of the Cambrian and associated beds of the Malvern Hills. The Quarterly Journal of the Geological Society of London 58, 89-149.

DOI 10.1144/GSL.JGS.1902.058.01-04.10

Hammersburg, S.R., Hasiotis, S.T., Robison, R.A., Gunther, L., Gunther, V. \& JAMison, P. 2013. The ichnotaxonomy of the Cambrian Spence Shale of Utah: Preliminary results. Geological Society of America Abstracts with Programs 45, 328.

Hollocher, K. \& Hollocher, T.C. 2012. Early processes in the fossilization of terrestrial feces to coprolites, and microstructure preservation. New Mexico Museum of Natural History and Science, Bulletin 57, 79-91.

Hu, S.X., Zhu, M.Y., Steiner, M., Luo, H.L., Zhao, F.C. \& Qi, L. 2010. Biodiversity and taphonomy window of the early Cambrian Guanshan biota, eastern Yunnan. Science China - Earth Sciences 53, 1765-1773. DOI 10.1007/s11430-010-4086-9

Hughes, N.C. 2001. Ecologic evolution of Cambrian trilobites, 370-403. In Zhuravlev, A.Y. \& Riding, R. (eds) The Ecology of the Cambrian Radiation. Columbia University Press, New York.

Hunt, A.P. 1992. Late Pennsylvanian coprolites from the Kinney Brick Quarry, central New Mexico with notes on the classification and utility of coprolites. New Mexico Bureau of Mines and Mineral Resources, Bulletin 138, 221-229.

Izumi, K. \& Yoshizawa, K. 2016. Star-shaped trace fossil and Phymatoderma from Neogene deep-sea deposits in central Japan: probable echiuran feeding and fecal traces. Journal of Paleontology 90, 1169-1180. DOI 10.1017/jpa.2016.95

Kimmig, J. \& PRATt, B.R. 2015. Soft-bodied biota from the middle Cambrian (Drumian) Rockslide Formation, Mackenzie Mountains, northwestern Canada. Journal of Paleontology 89, 51-71. DOI 10.1017/jpa.2014.5

Kimmig, J. \& Pratt, B.R. 2016. Depositional environment and taphonomy of the middle Cambrian (Drumian) Ravens Throat River Lagerstätte, Rockslide Formation, northwestern Canada. Lethaia 49, 150-169. DOI 10.1111/let.12135 
Kimmig, J., Strotz, L.C. \& Lieberman, B.S. (in press). The stalked filter feeder Siphusauctum lloydguntheri $\mathrm{n}$. sp. from the middle Cambrian (Series 3: Stage 5) Spence Shale of Utah: Its biological affinities and taphonomy. Journal of Paleontology.

Kloss, T.J., Dornbos, S.Q. \& Chen, J.Y. 2015a. Substrate adaptations of sessile benthic metazoans during the Cambrian radiation. Paleobiology 41, 342-352. DOI 10.1017/pab.2014.22

Kloss, T.J., Dornbos, S.Q., Chen, J.Y., McHenry, L.J. \& Marenco, P.J. 2015b. High-resolution geochemical evidence for oxic bottom waters in three Cambrian Burgess Shale-type deposits. Palaeogeography, Palaeoclimatology, Palaeoecology 440, 90-95. DOI 10.1016/j.palaeo.2015.08.048

Lachat, J. \& HaAg-Wackernagel, D. 2016. Novel mobbing strategies of a fish population against a sessile annelid predator. Scientific Reports 6, 33187. DOI 10.1038/srep33187

LegG, D.A. \& PAtes, S. 2017. A restudy of Utahcaris orion (Euarthropoda) from the Spence Shale (Middle Cambrian, Utah, USA). Geological Magazine 154, 181-186. DOI 10.1017/S0016756816000789

Lerosey-Aubril, R., Hegna, T.A., Kier, C., Bonino, E., Habersetzer, J. \& CarRé, M. 2012. Controls on gut phosphatization: the trilobites from the Weeks Formation Lagerstätte (Cambrian; Utah). PLoS ONE 7, e32934. DOI 10.1371/journal.pone.0032934

Liddell, W.D., Wright, S.H., \& Brett, C.E. 1997. Sequence stratigraphy and paleoecology of the Middle Cambrian Spence Shale in northern Utah and southern Idaho. Brigham Young University Geology Studies 42, 59-78.

Lieberman, B.S. 2003. A new soft-bodied fauna: The Pioche Formation of Nevada. Journal of Paleontology 77, 674-690. DOI 10.1017/S0022336000044413

Lieberman, B.S., Kurkewicz, R., Shinogle, H., Kimmig, J. \& MacGabhann, B.A. 2017. Disc-shaped fossils resembling porpitids (Cnidaria: Hydrozoa) from the early Cambrian (Series 2: Stage 4) of western U.S.A. PeerJ 5, e3312. DOI $10.7717 /$ peerj.3312

Lin, J.P., Zhao, Y.L., Rahman, I.A., XiaO, S. \& Wang, Y. 2010. Bioturbation in Burgess Shale-type Lagerstätten - Case study of trace fossil-body fossil association from the Kaili Biota (Cambrian Series 3), Guizhou, China. Palaeogeography, Palaeoclimatology, Palaeoecology 292, 245-256. DOI 10.1016/j.palaeo.2010.03.048

Liu, A.G., Kenchington, C.G. \& Mitchell, E.G. 2015. Remarkable insights into the paleoecology of the Avalonian Ediacaran macrobiota. Gondwana Research 27, 1355-1380. DOI 10.1016/j.gr.2014.11.002

Marenco, K.N. \& BotTJer, D.J. 2008. The importance of Planolites in the Cambrian substrate revolution. Palaeogeography, Palaeoclimatology, Palaeoecology 258, 189-199. DOI 10.1016/j.palaeo.2007.05.025

Martin, E.L.O., Lerosey-Aubril, R. \& VAnnier, J. 2016. Palaeoscolecid worms from the Lower Ordovician Fezouata Lagerstätte, Morocco: palaeoecological and palaeogeographical implications. Palaeogeography, Palaeoclimatology, Palaeoecology 460, 130-141.

DOI 10.1016/j.palaeo.2016.04.009
McMahon, S. Tarhan, L. \& Briggs, D.E.G. 2017. Decay of the sea anemone Metridium (Actiniaria): Implications for the preservation of soft-bodied diploblast-grade animals. Palaios 32, 388-395. DOI 10.2110/palo.2016.102

Mikuláš, R. 1995. Trace fossils from the Paseky Shale (Early Cambrian, Czech Republic). Journal of the Czech Geological Society 40, 37-54.

Moore, R.A. \& Lieberman, B.S. 2009. Preservation of early and Middle Cambrian soft-bodied arthropods from the Pioche Shale, Nevada, USA. Palaeogeography, Palaeoclimatology, Palaeoecology 277, 57-62.

DOI 10.1016/j.palaeo.2009.02.014

Nedin, C. 1999. Anomalocaris predation on nonmineralized and mineralized trilobites. Geology 27, 987-990.

DOI 10.1130/0091-7613(1999)027<0987:APONAM>2.3.CO;2

Nicholson, H.A. 1873. Contributions to the study of the errant annelids of the older Palaeozoic rocks. Proceedings of the Royal Society of London 21, 288-290. DOI 10.1098/rspl.1872.0061

PeEL, J.S. 2015. Bromalites from the Cambrian (Series 2 and 3) of North Greenland. GFF 137, 181-194. DOI 10.1080/11035897.2014.995217

PeEL, J.S. 2017. Mineralized gutfills from the Sirius Passet Lagerstätte (Cambrian Series 2) of North Greenland. GFF 139, 83-91. DOI 10.1080/11035897.2016.1260051

Pickerill, R.K., \& NARBonNe, G.M. 1995. Composite and compound ichnotaxa: a case example from the Ordovician of Québec, eastern Canada, Ichnos 4, 53-69.

DOI 10.1080/10420949509380114

Rigby, J.K. 1983. Sponges of the Middle Cambrian Marjum Limestone from the House Range and Drum Mountains of western Millard County, Utah. Journal of Paleontology 57, 240-270.

Robison, R.A. 1969. Annelids from the middle Cambrian Spence Shale of Utah. Journal of Paleontology 43, 1169-1173.

RoBISON, R. A. 1991. Middle Cambrian biotic diversity: examples from four Utah lagerstätten, 77-98. In Simonetta, A. \& CONway Morris, S. (eds) The Early Evolution of Metazoa and the Significance of Problematic Taxa. Cambridge University Press, Cambridge.

Robison, R.A., BAbcock, L.E. \& Gunther, V.G. 2015. Exceptional Cambrian fossils from Utah. A window into the age of trilobites. Utah Geological Survey Miscellaneous Publication 15-1, 1-97.

Sappenfield, A.D., Tarhan, L.G. \& Droser, M.L. 2017. Earth's oldest jellyfish strandings: A unique taphonomic window or just another day at the beach? Geological Magazine 154, 859-574. DOI 10.1017/S0016756816000443

SCHÄFER, W. 1953. Zur Unterscheidung gleichförmiger Kot-Pillen meerischer Evertebraten. Senckenbergiana 34, 81-93.

Schweigert, G., Seegis, D.B., Fels, A. \& Leinfelder, R.R. 1997. New internally structured decapod microcoprolites from Germany (Late Triassic/Early Miocene), Southern Spain (Early/Middle Jurassic) and Portugal (Late Jurassic): Taxonomy, palaeoecology and evolutionary implications. 
Paläontologische Zeitschrift 71, 51-69. DOI 10.1007/BF03022546

SeIlacher, A. 2007. Trace Fossil Analysis. 226 pp. Springer Verlag, Berlin, Heidelberg, New York.

Selly, T., Huntley, J.W., Shelton, K.L. \& Schiffbauer, J.D. 2016. Ichnofossil record of selective predation by Cambrian trilobites. Palaeogeography, Palaeoclimatology, Palaeoecology 444, 28-38. DOI 10.1016/j.palaeo.2015.11.033

Senowbari-Daryan, B. \& Kube, B. 2003. The ichnogenus Palaxius (crustacean coprolite) and description of $P$. hydranensis n. sp. from the Upper Triassic (Norian part of "Pantokrator" limestone) of Hydra (Greece). Paläontologische Zeitschrift 77, 115-122. DOI 10.1007/BF03004563

Shen, C., Pratt, B.R. \& Zhang, X.G. 2014. Phosphatized coprolites from the middle Cambrian (Stage 5) Duyun fauna of China. Palaeogeography, Palaeoclimatology, Palaeoecology 410, 104-112. DOI 10.1016/j.palaeo.2014.05.035

Slater, B.J., McLoughlin, S. \& Hilton, J. 2012. Animal-plant interactions in a Middle Permian permineralised peat of the Bainmedart Coal Measures, Prince Charles Mountains, Antarctica. Palaeogeography, Palaeoclimatology, Palaeoecology 363-364, 109-126. DOI 10.1016/j.palaeo.2012.08.018

SPRINKLE, J. 1973. Morphology and evolution of blastozoan echinoderms. Museum of Comparative Zoology, Harvard University, Special Publication, 1-283.

Tarhan, L.G., Jensen, S. \& Droser, M.L. 2011. Furrows and firmgrounds: Evidence for predation and implications for Palaeozoic substrate evolution in Rusophycus burrows from the Silurian of New York. Lethaia 45, 329-341. DOI 10.1111/j.1502-3931.2011.00286.x

VALENTine, J.W. 1995. Late Precambrian bilaterians: grades and clades, 87-107. In Fitch, W.M. \& Ayala, F.J. (eds) Tempo and Mode in Evolution: Genetics and Paleontology 50 Years After Simpson. National Academy Press, Washington, D.C.
VANNIER, J. 2012. Gut contents as direct indicators for trophic relationships in the Cambrian marine ecosystem. PLoS One 7, e52200. DOI 10.1371/journal.pone. 0052200

VAnNiER, J. \& ChEN, J. 2005. Early Cambrian food chain: new evidence from fossil aggregates in the Maotianshan Shale biota. Palaios 20, 3-26. DOI 10.2110/palo.2003.p03-40

VANNIER, J. \& MARTin, E.L.O. 2017. Worm-lobopodian assemblages from the Early Cambrian Chengjiang biota: Insight into the "pre-arthropodan ecology"? Palaeogeography, Palaeoclimatology, Palaeoecology 468, 373-387.

DOI 10.1016/j.palaeo.2016.12.002

Vannier, J., Calandra, I., Gaillard, C. \& Zylinska, A. 2010. Priapulid worms: pioneer horizontal burrowers at the Precambrian-Cambrian boundary. Geology 38, 711-714. DOI 10.1130/G30829.1

Vannier, J., Liu, J., Lerosey-Aubril, R., Vinther, J. \& Daley, A. C. 2014. Sophisticated digestive systems in early arthropods. Nature Communications 5, 3641 .

DOI 10.1038/ncomms4641

Weber, B., Hu, S., Steiner, M. \& Zhao, F.C. 2012. A diverse ichnofauna from the Cambrian Stage 4 Wulongqing Formation near Kunming (Yunnan Province, South China). Bulletin of Geosciences 87, 71-92. DOI 10.3140/bull.geosci.1239

Webster, M., Gaines, R.R. \& Hughes, N.C. 2008. Microstratigraphy, trilobite biostratinomy, and depositional environment of the "Lower Cambrian" Ruin Wash Lagerstätte, Pioche Formation, Nevada. Palaeogeography, Palaeoclimatology, Palaeoecology 264, 100-122.

DOI 10.1016/j.palaeo.2008.04.002

Whittington, H.B. 1985. The Burgess Shale. 151 pp. Yale University Press, New Haven, Connecticut.

Zacaï, A., VAnnier, J. \& Lerosey-Aubril, R. 2016. Reconstructing the diet of a 505-million-year-old arthropod: Sidneyia inexpectans from the Burgess Shale fauna. Arthropod Structure and Development 45, 200-220.

DOI 10.1016/j.asd.2015.09.003 